\section{Yellow Fever Virus RNA in Urine and Semen of Convalescent Patient, Brazil}

\author{
Carla M. Barbosa, ${ }^{1,2}$ Nicholas Di Paola, ${ }^{1}$ \\ Marielton P. Cunha, ${ }^{1}$ Mônica J. Rodrigues-Jesus, \\ Danielle B. Araujo, Vanessa B. Silveira, \\ Fabyano B. Leal, Flávio S. Mesquita, \\ Viviane F. Botosso, Paolo M.A. Zanotto, \\ Edison L. Durigon, Marcos V. Silva, \\ Danielle B.L. Oliveira
}

Author affiliations: University of São Paulo, São Paulo, Brazil (C.M. Barbosa, N. Di Paolo, M.P. Cunha, M.J. Rodrigues-Jesus, D.B. Araujo, V.B. Silveira, F.B. Leal, F.S. Mesquita, P.M.A. Zanotto, E.L. Durigon, D.B.L. Oliveira); Butantan Institute, São Paulo

(V.F. Botosso); Institute of Infectology Emilio Ribas, São Paulo

(M.V. Silva); Pontifical Catholic University, São Paulo

(M.V. Silva)

DOI: https://doi.org/10.3201/eid2401.171310

Yellow fever virus RNA is usually detected in blood of infected humans. We detected virus RNA in urine and semen samples from a convalescent patient. A complete virus genome was sequenced for an isolate from a urine sample. This virus had a South American I genotype and unique synapomorphic changes.

Y ellow fever virus (YFV) is a member of the genus Flavivirus and causes yellow fever in humans, characterized by fever, prostration, and hepatic, renal, and myocardial complications that lead to death in $20 \%-50 \%$ of cases (1). Clinical confirmation of YFV infections is based on detection of virus RNA in blood by reverse transcription PCR or antigen-based ELISAs. Detection of virus in urine samples has been used for confirming infections with flaviviruses, including West Nile virus (2), Zika virus (3), dengue virus (4), and YFV (5).

Despite availability of an effective vaccine, $>200,000$ cases of yellow fever and $>30,000$ deaths occur per year (6). A large epidemic of yellow fever with high death rates recently occurred in Brazil. In December 2016, the first cases of yellow fever during this epidemic were reported in Minas Gerais; cases were later identified in Espírito Santo, Goiás, Mato Grosso, Pará, Rio de Janeiro, São Paulo, Tocantins, and the Federal District. There were 792 confirmed cases and 274 deaths (case-fatality rate $35 \%$ ) as of July 10, 2017 (7). We report a case of yellow fever in a 65-year-old man who was a native of São Paulo and had

${ }^{1}$ These authors contributed equally to this article.

${ }^{2}$ Current affiliation: Pirbright Institute, Pirbright, UK. not been vaccinated against yellow fever. The study protocol was approved by the Ethics Committee on Research with Human Beings at the University of São Paulo. The patient provided informed consent for use of the samples during the study.

The patient had traveled to Januária, Minas Gerais, Brazil, on December 28, 2016, and to a rural area north of São Paulo on January 3, 2017. On January 6, he had fever, chills, body pain, and nausea. During days $1-3$ after symptom onset, more severe symptoms developed: persistent fever (temperature $39.5^{\circ} \mathrm{C}-40^{\circ} \mathrm{C}$ ), headache, body pain, prostration, vomiting, dizziness, anorexia, dark stools, dark yellow urine, and bitterness in the mouth.

The patient was admitted to a public hospital in Januária on January 9. An ELISA for nonstructural protein 1 (NS1) of dengue virus showed a negative result. The patient also had severe thrombocytopenia (platelet count $77,000 / \mathrm{mm}^{3}$

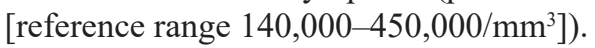

On January 13, the patient returned to São Paulo and was admitted to a public hospital. Another ELISA for dengue virus NS1 was performed and showed a negative result. His platelet count decreased to $57,000 / \mathrm{mm}^{3}$. On January 16 , the patient was admitted to a reference hospital for infectious diseases in São Paulo. He showed a moderate clinical presentation: anicteric form and mild spontaneous hemorrhage (ecchymosis in the right eye). High fever, gastrointestinal symptoms (vomiting and diarrhea), weakness, adynamia, and generalized myalgia were also observed. The patient had a weight loss of $4 \mathrm{~kg}$ over 8 days. Serum and urine samples were obtained (Figure, panel A; online Technical Appendix, https://wwwnc.cdc.gov/EID/ article/24/1/17-1310-Techapp1.pdf).

We extracted virus RNA by using the NucliSENS EasyMag Kit (bioMérieux, Marcy l'Étoile, France). We tested samples for YFV by using a real-time quantitiative reverse transcription PCR (qRT-PCR) and primers specific for YFV (8) and a conventional PCR and pan flavivirus primers (9). Serum samples showed negative results for both PCRs. However, a urine sample obtained 10 days after initial symptoms was positive for YFV RNA (cycle threshold $\left[\mathrm{C}_{\mathrm{t}}\right] 17.42,9.3 \times 10^{6} \mathrm{RNA}$ copies $/ \mathrm{mL}$ ) by qRT-PCR. We also performed a qualitative IgM-capture ELISA with a specific virus antigen and obtained positive results (optical density 1.19) (10).

On January 27, we obtained serum, urine, and semen samples and tested them by using qRT-PCR. Urine $\left(\mathrm{C}_{\mathrm{t}}\right.$ $28.57,3.3 \times 10^{3}$ RNA copies $\left./ \mathrm{mL}\right)$ and semen $\left(\mathrm{C}_{t} 31.00,5 \times\right.$ $10^{2}$ RNA copies $/ \mathrm{mL}$ ) samples were positive for YFV RNA. To evaluate infectivity, we tested a urine sample obtained on this date (online Technical Appendix). We isolated YFV in cell culture, which confirmed virus integrity. We also confirmed infectivity after a second virus passage $\left(\mathrm{C}_{\mathrm{t}}\right.$ $24.35,6.7 \times 10^{4} \mathrm{RNA}$ copies $/ \mathrm{mL}$ ). 
For the urine sample that was positive for YFV RNA by qRT-PCR, we directly characterized viral diversity by using next-generation sequencing (online Technical Appendix). In South America, phylogenetic studies have inferred 2 circulating YFV genotypes. The isolate from our patient (BRMG-2017) clustered with South America I isolates, including 2 viruses isolated in 2017 in Espírito Santo, a state bordering Minas Gerais, and other viruses isolated previously in Brazil (Figure, panel B).

We did not observe any insertions or deletions in BRMG-2017 nucleotide sequences when compared with sequences of other South America I strains. However, several synapomorphic changes were detected (V108I [capsid], E1572D [NS3], R1605K [NS3], K2608R [NS5], V2645I [NS5], G2680S [NS5], N2804S [NS5], V3150A [NS5], and N3216S [NS5]). Most of these changes were located in the NS5 (RNA-dependent RNA polymerase) gene, which plays a major role in virus replication. Changes in the NS5 gene have been associated with differences in viral replication, immune response, and protein-protein interactions during virus replication.

Our results suggest that semen can be a useful clinical material for diagnosis of yellow fever and indicate the need for testing urine and semen samples from patients

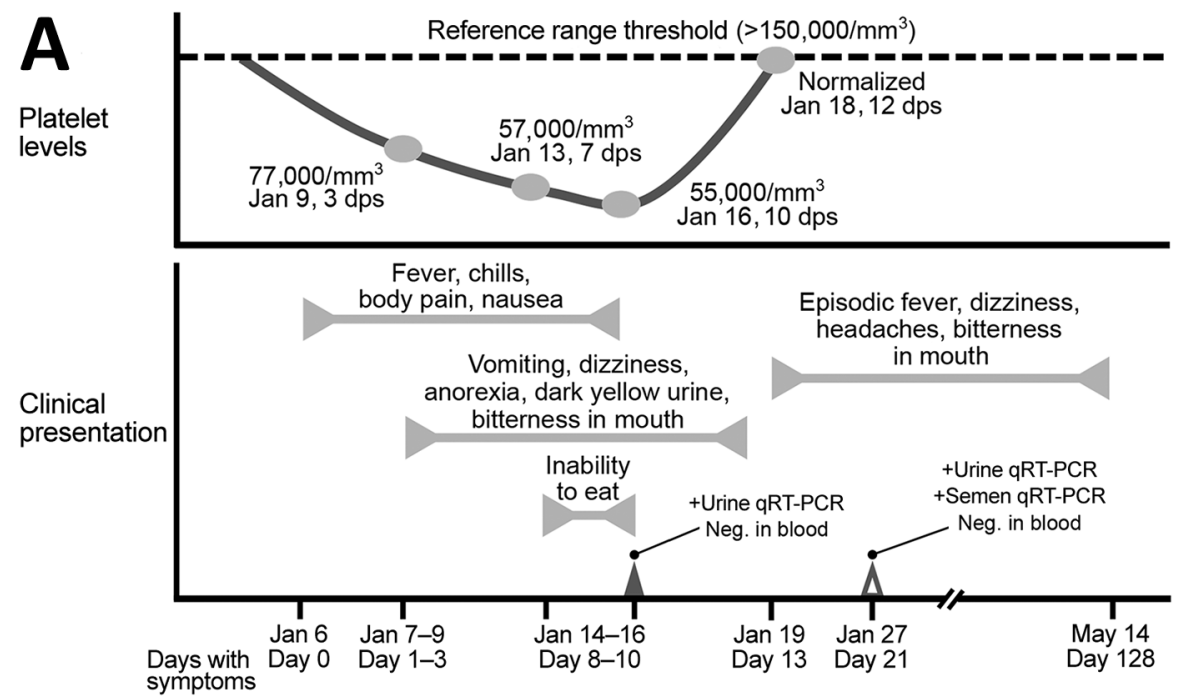

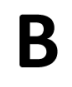

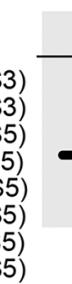

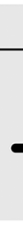

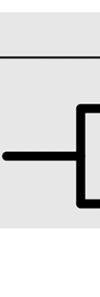

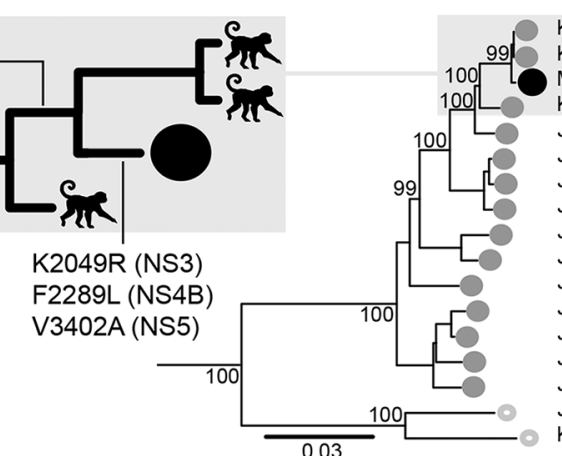

KY885001_BRES_2017 KY885000 BRES 2017 MF465805_BRMG_2017 KY861728_BRRG_2008 JF912190_BRRR_2002 JF912188_BRGO_2000 JF912187 BRGO 2000 JF912189 BRRS 2001 JF912185_BRMS_1992 JF912182_BRPA_ 1984 JF912180_BRPA_1981 JF912184_BRPA_1987 JF912179_BRGO_1980 JF912183_BRPA_1984 JF912186_BRMG_1994 JF912181_BRRO_1983 KF907504_BO_1999

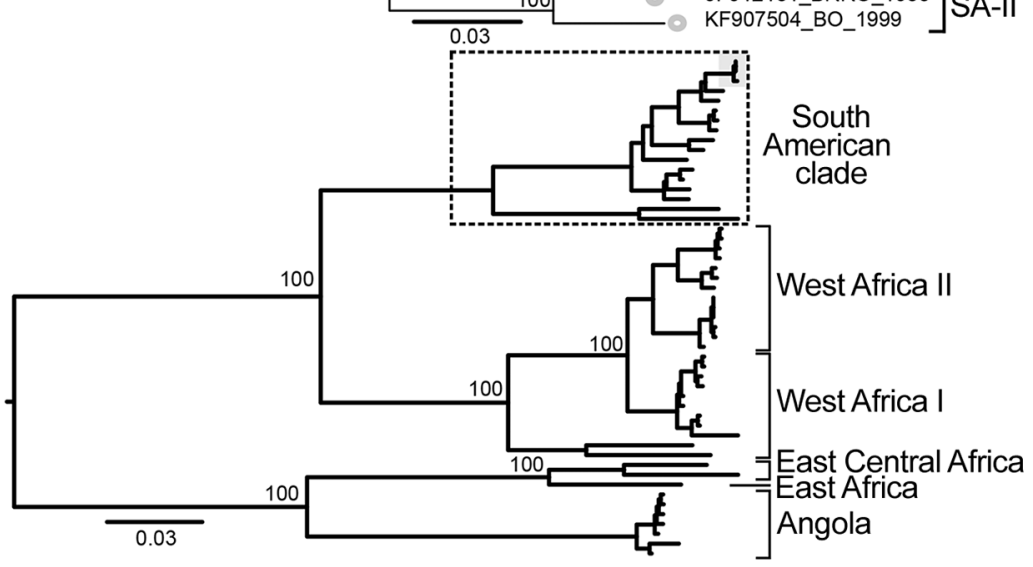

Figure. Clinical progression and detection of YFV RNA in urine and semen of convalescent patient, Brazil. A) Platelet levels, clinical parameters and symptoms, and test results over a 128-day period after initial symptoms were observed. B) Maximum-likelihood tree (midpoint-rooted) inferred by using complete genomes of YFV to distinguish major virus genotypes; dashed box indicates South American clade strains, enlarged at top. Numbers near nodes indicate percent bootstrap values after 10,000 replicates for major branches. Black circles indicate virus isolated in this study. Shaded boxes indicate monkey-derived virus sister taxa sampled during the same outbreak; inset at top left shows most parsimonious reconstructions of synapomorphic changes detected NS3, NS4B, and NS5 genes. GenBank accession number, geographic location code, and year of isolation are shown for virus isolates. Scale bars indicate nucleotide substitutions per site. C, capsid; dps, days postsymptom onset; Neg., negative; NS, nonstructural; qRT-PCR, quantitative reverse transcription PCR; SA, South America clade; YFV, yellow fever virus; +, positive. 
with advanced disease. Such testing could improve diagnostics, reduce false-negative results, and strengthen the reliability of epidemiologic data during ongoing and future outbreaks.

\section{Acknowledgments}

We thank Thaigo A. Souza and the technical team at Centro de Facilidades de Apoio a Pesquisa for providing assistance; Cinthia Bombardieri and staff of the 2016 Pensabio/Illumina Award Program for providing guidance and technical support; and Luciano M. Thomazelli for providing technical support.

This study was supported by Fundação de Amparo à Pesquisa do Estado de São Paulo (FAPESP) projects 2016/08727-5 and 2014/17766-9 and Conselho Nacional de Pesquisa (CNPq) project 441105/2016-5. N.D. was supported by a fellowship from FAPESP (2013/22136-1), M.P.C. was supported by a fellowship from FAPESP (2016/08204-2), M.J.R.-J. was supported by a fellowship from FAPESP (2014/21141-4), V.B.S. was supported by a fellowship from FAPESP (2016/10161-0), and C.M.B. was supported by a fellowship from CNPq (88887.141172/2017-00) and the Coordenação de Aperfeiçoamento de Pessoal de Nível Superior//Newton Fund (Institutional links 99999.005126/2015/00).

\section{About the Author}

Dr. Barbosa is a veterinarian and doctoral candidate at the University of São Paulo, São Paulo, Brazil, and Pirbright Institute, Pirbright, UK. Her research interests are molecular biology, cell culture, and animal and human virology.

\section{References}

1. Beasley DW, McAuley AJ, Bente DA. Yellow fever virus: genetic and phenotypic diversity and implications for detection, prevention and therapy. Antiviral Res. 2015;115:48-70. http://dx.doi.org/10.1016/j.antiviral.2014.12.010

2. Barzon L, Pacenti M, Franchin E, Pagni S, Martello T, Cattai M, et al. Excretion of West Nile virus in urine during acute infection. J Infect Dis. 2013;208:1086-92. http://dx.doi.org/10.1093/infdis/ jit290

3. Gourinat A-C, O’Connor O, Calvez E, Goarant C, Dupont-Rouzeyrol M. Detection of Zika virus in urine. Emerg Infect Dis. 2015;21:84-6. http://dx.doi.org/10.3201/ eid2101.140894

4. Andries A-C, Duong V, Ly S, Cappelle J, Kim KS, Lorn Try P, et al. Value of routine dengue diagnostic tests in urine and saliva specimens. PLoS Negl Trop Dis. 2015;9:e0004100. http://dx.doi.org/10.1371/journal.pntd.0004100

5. Reuskena CB, Knoesterb M, GeurtsvanKessel C, Koopmans M, Knapend DG, Biermand WF, et al. Urine as sample for molecular diagnosis of natural yellow fever virus infections. J Clin Microbiol. 2017; Aug 30 [Epub ahead of print]. http://dx.doi.org/10.1128/JCM.01113-17.

6. Bryant JE, Holmes EC, Barrett AD. Out of Africa: a molecular perspective on the introduction of yellow fever virus into the Americas. PLoS Pathog. 2007;3:e75. http://dx.doi.org/10.1371/ journal.ppat.0030075
7. Pan American Health Organization. Epidemiological update: yellow fever, July 10, 2017 [cited 2017 Oct 6]. http://reliefweb. int/sites/reliefweb.int/files/resources/2017-jul-10-phe-epi-updateyellow-fever.pdf

8. Diallo D, Sall AA, Diagne CT, Faye O, Hanley KA, Buenemann M, et al. Patterns of a sylvatic yellow fever virus amplification in southeastern Senegal, 2010. Am J Trop Med Hyg. 2014;90:1003-13. http://dx.doi.org/ 10.4269/ ajtmh.13-0404

9. Johnson N, Wakeley PR, Mansfield KL, McCracken F, Haxton B, Phipps LP, et al. Assessment of a novel real-time pan-flavivirus RT-polymerase chain reaction. Vector Borne Zoonotic Dis. 2010;10:665-71. http://dx.doi.org/10.1089/ vbz.2009.0210

10. Oliveira DB, Almeida FJ, Durigon EL, Mendes ÉA, Braconi CT, Marchetti I, et al. Prolonged shedding of Zika virus associated with congenital infection. N Engl J Med. 2016;375:1202-4. http://dx.doi.org/10.1056/NEJMc1607583

Address for correspondence: Danielle B. L. Oliveira, Departamento de Microbiologia, Instituto de Ciências Biomédicas II, Universidade de São Paulo, Av. Prof. Lineu Preste, 1374 CEP 05580-900, São Paulo, Brazil; email: danibruna@gmail.com

\section{Molecular Characterization of Autochthonous Chikungunya Cluster in Latium Region, Italy}

\author{
Licia Bordi, Fabrizio Carletti, Eleonora Lalle, \\ Francesca Colavita, Silvia Meschi, \\ Antonino Di Caro, Emanuele Nicastri, \\ Paola Scognamiglio, Francesco Vairo, \\ Domenico Di Lallo, Vincenzo Panella, \\ Maria R. Capobianchi, Giuseppe Ippolito, \\ Concetta Castilletti
}

\begin{abstract}
Author affiliations: Lazzaro Spallanzani National Institute for Infectious Diseases, Rome, Italy (L. Bordi, F. Carletti, E. Lalle, F. Colavita, S. Meschi, A. Di Caro, E. Nicastri, P. Scognamiglio, F. Vairo, M.R. Capobianchi, G. Ippolito, C. Castilletti); Regional Service for Surveillance and Control of Infectious Diseases, Rome (P. Scognamiglio, F. Vairo); Regional Health and Social Policy Department, Lazio Region, Rome (D. Di Lallo, V. Panella)
\end{abstract}

DOI: https://doi.org/10.3201/eid2401.171605 